Abstracta Iranica Abstracta Iranica

Revue bibliographique pour le domaine irano-aryen

Volume 28 | 2007

Comptes rendus des publications de 2005

\title{
Iran : regard vers l'Est : la politique asiatique de la République islamique. Bruxelles, GRIP, 2005, 36 p.
}

\section{Anicée Van Engeland}

\section{(2) OpenEdition}

1 Journals

\section{Édition électronique}

URL : http://journals.openedition.org/abstractairanica/18901

DOI : 10.4000/abstractairanica.18901

ISSN : 1961-960X

Éditeur :

CNRS (UMR 7528 Mondes iraniens et indiens), Éditions de l'IFRI

\section{Édition imprimée}

Date de publication : 15 mai 2007

ISSN : 0240-8910

\section{Référence électronique}

Anicée Van Engeland, «Iran : regard vers l'Est : la politique asiatique de la République islamique. Bruxelles, GRIP, 2005, 36 p. », Abstracta Iranica [En ligne], Volume 28 | 2007, document 414, mis en ligne le 18 septembre 2007, consulté le 25 septembre 2020. URL : http://journals.openedition.org/ abstractairanica/18901 ; DOI : https://doi.org/10.4000/abstractairanica.18901

Ce document a été généré automatiquement le 25 septembre 2020.

Tous droits réservés 


\title{
Iran : regard vers l'Est : la politique asiatique de la République islamique. Bruxelles, GRIP, 2005, 36
} p.

\author{
Anicée Van Engeland
}

1 Quelles relations politiques, économiques, énergétiques l'Iran entretient-il avec l'Inde, la Chine et le Japon ? C'est à cette question que ce rapport tente de répondre : il met en lumière les relations que l'Iran entretien avec l'Est: elles se sont intensifiées et consolidées depuis l'avènement de la République islamique ; ces pays sont liés par des intérêts économiques, politiques et énergétiques communs. L'Iran peut ainsi ouvrir de nouvelles perspectives politiques et de nouveaux marchés économiques. C'est aussi par ce biais que l'Iran obtient ses armes et améliore sa connaissance du nucléaire. Le rapport à l'Inde constitue un partenariat stratégique car l'Inde est une voie de transit pour le commerce du gaz et du pétrole. Les relations avec la Chine représentent beaucoup en relations internationales et c'est pour cela que l'Iran a intensifié la coopération, particulièrement depuis le 11 septembre 2001 : les deux pays trouvent un intérêt économique à commercer à une époque où les frontières se ferment. Cet intérêt n'est pas qu'économique mais est aussi politique tout comme l'est le rapport avec le Japon.

2 Ce regard vers l'Est assure l'indépendance de l'Iran face aux puissances occidentales. Le rapport conclut que les relations de l'Iran avec l'Inde, la Chine et le Japon assurent à l'Iran une position sur l'échiquier international du futur. 
INDEX

Thèmes : 13.1. Iran

\section{AUTEURS}

ANICÉE VAN ENGELAND

Paris 